NBER WORKING PAPER SERIES

\title{
CROSS-COUNTRY CAUSES AND CONSEQUENCES OF THE 2008 CRISIS: INTERNATIONAL LINKAGES AND AMERICAN EXPOSURE
}

\author{
Andrew K. Rose \\ Mark M. Spiegel \\ Working Paper 15358 \\ http://www.nber.org/papers/w15358 \\ NATIONAL BUREAU OF ECONOMIC RESEARCH \\ 1050 Massachusetts Avenue \\ Cambridge, MA 02138 \\ September 2009
}

Rose is B.T. Rocca Jr. Professor of International Trade and Economic Analysis and Policy in the Haas School of Business at the University of California, Berkeley, NBER Research Associate and CEPR Research Fellow. Spiegel is Vice President, Economic Research, Federal Reserve Bank of San Francisco. Rose thanks EIEF, MAS and NUS for hospitality during the course of this research. Christopher Candelaria provided excellent research assistance. The views expressed below do not represent those of the Federal Reserve Bank of San Francisco or the Board of Governors of the Federal Reserve System. A current version of this paper, key output, and the main STATA data set used in the paper are available at http://faculty.haas.berkeley.edu/arose. The views expressed herein are those of the author(s) and do not necessarily reflect the views of the National Bureau of Economic Research.

NBER working papers are circulated for discussion and comment purposes. They have not been peerreviewed or been subject to the review by the NBER Board of Directors that accompanies official NBER publications.

(C) 2009 by Andrew K. Rose and Mark M. Spiegel. All rights reserved. Short sections of text, not to exceed two paragraphs, may be quoted without explicit permission provided that full credit, including (C) notice, is given to the source. 
Cross-Country Causes and Consequences of the 2008 Crisis: International Linkages and American Exposure

Andrew K. Rose and Mark M. Spiegel

NBER Working Paper No. 15358

September 2009

JEL No. E65,F30

\begin{abstract}
This paper models the causes of the 2008 financial crisis together with its manifestations, using a Multiple Indicator Multiple Cause (MIMIC) model. Our analysis is conducted on a cross-section of 85 countries; we focus on international linkages that may have allowed the crisis to spread across countries. Our model of the cross-country incidence of the crisis combines 2008 changes in real GDP, the stock market, country credit ratings, and the exchange rate. We explore the linkages between these manifestations of the crisis and a number of its possible causes from 2006 and earlier. The causes we consider are both national (such as equity market run-ups that preceded the crisis) and, critically, international financial and real linkages between countries and the epicenter of the crisis. We consider the United States to be the most natural origin of the 2008 crisis, though we also consider six alternative sources of the crisis. A country holding American securities that deteriorate in value is exposed to an American crisis through a financial channel. Similarly, a country which exports to the United States is exposed to an American downturn through a real channel. Despite the fact that we use a wide number of possible causes in a flexible statistical framework, we are unable to find strong evidence that international linkages can be clearly associated with the incidence of the crisis. In particular, countries heavily exposed to either American assets or trade seem to behave little differently than other countries; if anything, countries seem to have benefited slightly from American exposure.
\end{abstract}

\author{
Andrew K. Rose \\ Haas School of Business Administration \\ University of California, Berkeley \\ Berkeley, CA 94720-1900 \\ and NBER \\ arose@haas.berkeley.edu \\ Mark M. Spiegel \\ Federal Reserve Bank of San Francisco \\ 101 Market Street \\ San Francisco, CA 94105 \\ mark.spiegel@sf.frb.org
}


"An early warning system must be established to identify upstream increases in risks..."

- Heads of State or Government of European Union, November $72008 .^{1}$

"The Group recommends that the IMF, in close cooperation with other interested bodies ... is put in charge of developing and operating a financial stability early warning system, accompanied by an international risk map and credit register. The early warning system should aim to deliver clear messages to policy makers and to recommend pre-emptive policy responses..."

- De Larosiere Report, February 25 2009. ${ }^{2}$

\section{Introduction}

In Rose and Spiegel (2009), hereafter "RS", we modeled the causes of the 2008 financial crisis together with its manifestations, using a Multiple Indicator Multiple Cause (MIMIC) model. In that paper, we focused on national causes and consequences of the crisis and deliberately ignored cross-country "contagion" effects. This paper is intended to fill that gap; it empirically models various channels through which a shock that hits one or more countries might then be transmitted internationally.

We follow RS closely so as to make our results as complementary as possible. Our analysis is conducted on the same broad cross-section of countries. Our model of the incidence of the crisis is the same, combining 2008 changes in a) real GDP, b) the stock market, c) country credit ratings, and d) the exchange rate into a single measure of crisis incidence. We also control for national causes of the crisis identified by RS, dated from 2006 and earlier. These national causes are relevant parts of an early warning system if crises are country-specific in nature. They are also important if common international shocks hit a number of countries simultaneously, but a country's vulnerability to common shocks is determined by national 
characteristics. However, the national focus of RS is inappropriate if crises begin in one country and then spread contagiously across national borders. Accordingly, we expand our search and focus on international linkages in this paper.

We emphasize at the outset that this project has a limited scope. Two blinkers are particularly important. First, our analysis is cross-sectional in nature, and is focused deliberately on a period of time when we know there was a major financial/economic crisis that affected a large number of countries. That is, we make no attempt at all to model the timing of the crisis. We consider the latter to be a more challenging objective than ours, which is merely to determine the incidence of the 2008 crisis across countries. Success in predicting the crosssectional intensity of the crisis is a necessary condition for a useful early warning system, but is far from being sufficient. Second, with the benefit of hindsight, we do not have to model the epicenter of the 2008 crisis, a critical ingredient for any model of contagion. Though we consider a number of alternatives, it seems reasonable to model the United States as the epicenter of the 2008 financial crisis. Even strong evidence of contagion would be difficult to use in a serious early warning system, since future crises epicenters are unknown.

\section{Literature Review}

\section{Concepts: Common Shocks vs. International Transmission of Shocks}

The existence of international linkages or "contagion" in previous crises (exchange rate, banking, and financial) is controversial. The controversy begins with disagreement concerning the appropriate definition of the phenomenon. The issue is that common movements at a point in time may either be manifestations of common shocks that hit different countries 
differently, or shocks from one or more countries that spill out contagiously via different channels of transmission. Common shocks and contagion may be observationally similar. However, they represent different phenomena, with radically different policy implications (for instance, "isolation" is appropriate for contagion but not common shocks).

A number of authors [e.g. Forbes and Rigobon (2001) and Edwards (2002)] take a more narrow view of contagion. They argue that both common shocks and the international transmission of external shocks are observed in tranquil periods as well as episodes of crisis. In the tradition of epidemiological studies, "true contagion" is then a larger-than-expected effect of foreign shocks. They therefore define contagion as an exceptional increase in the magnitude of international linkages, such as the 50 percent fall in the Brazilian stock market subsequent to the collapse of the Russian ruble in 1998. Forbes and Rigobon (2001) refer to this narrower concept as "shift contagion."

Using this concept, Forbes and Rigobon (2002) find no evidence of "contagion" for a number of crises. However, they do find what they call "interdependence," the cross-country correlation of asset prices during tranquil and periods alike. Similarly, Bekaert, et al (2005) find no evidence of increases in correlations subsequent to the 1995 peso crisis, although they do find evidence after the 1997 Asian crisis. For the current crisis, Eichengreen, et al (2009) find that sensitivity to common shocks increased at the Fall 2008 volatility peaks for bank credit default swap spreads, using data for 45 large banks in Europe and the United States.

For our cross-sectional study of the 2008 crisis, examining whether correlations rise is impossible, as our sample only considers a single episode. However, it seems possible, in 
principle, to distinguish between country-specific sensitivity to common shocks and the country-specific contagious responses to particular foreign shocks. A country's response to a common shock seems to be a multilateral phenomena (e.g., more financially developed economies might respond to a common increase in risk aversion), while the contagious response to an individual foreign shock seems to be intrinsically bilateral (e.g., countries with more exposure to American assets might respond more to a decline in American asset prices). In RS, we attempted to model multilateral phenomena using national data; in this paper, we focus on bilateral phenomena in our search for contagion.

\section{Empirical Evidence on Channels of Contagion}

Even if there is evidence of contagion, there are different channels of transmission through which countries can be linked. Two are of particular interest: a real channel that focuses on international trade, and a financial channel that is concerned with asset crossholdings.

\section{Trade Linkages}

Countries linked through international trade may experience contagion if their trading partners devalue their currencies. That is, strong trade linkages may encourage devaluation (or self-fulfilling expectations thereof) in response to foreign currency shocks, since countries wish to maintain external competitiveness. The basic mechanisms have been spelled out by Gerlach and Smets (1995) and Huh and Kasa (2001). Crisis contagion can also hit economies through declines in merchandise trade [e.g. Reisen (2008)]. 
Most studies in the literature stress the channel of contagion through foreign trade linkages. The intensity of trade linkages between two countries has been measured as the share of bilateral trade between the two countries in total trade [e.g. Eichengreen, Rose, and Wyplosz (1996) and Forbes and Chinn (2004)]. As a form of contagion of a specific crisis, trade exposure has been measured in this manner relative to the "ground zero" country where the crisis first started, as in Glick and Rose (1999) and Van Rijckeghem and Weder (2001), or in the case of a regional crisis such as the 1997 Asian crisis, the sum of bilateral exposure to the affected countries within the region, as in Baig and Goldfajn (1999). At the firm level, Forbes (2004) measures the intensity of exposure of firms to the Russian and Asian crises of the late 1990s as a zero-one variable based on whether sales to those countries exceeded $5 \%$ of total sales.

Other measures of trade linkages in the literature look for common competitors, as in Baig and Goldfajn (1999), who examine exposure to the United States and Japan, or Glick and Rose (1999), Van Rijckeghem and Weder (2001) and Forbes (2002), who measure the degree to which a country's exports compete with those of the ground zero country. For example, Forbes (2002) measures this as the product of the share of exports from the ground zero country to total global trade in that industry (a measure of the importance of the ground zero country in global trade in that industry), and the share of trade in that industry in that country's GDP (a measure of the importance of trade in that industry to the affected country).

In the case of the current crisis, the common competitor channel seems less important, as the epicenter of the crisis was the United States, an important exporter globally, but one 
whose export bundle and trading partners seems to be unique. It seems much more likely that the primary trade impact of the crisis was lost export opportunities, initially in the United States, but then in other countries as they experienced their own downturns. As such, we concentrate on the exposure channel of the importance of a country as a trading partner below.

Most of the studies find evidence that trade linkages matter. Eichengreen, Rose and Wyplosz (1996) find that trade linkages explain contagion patterns in currency crises across a group of industrial countries. Glick and Rose (1999) find that currency crises tend to be

regional, supporting the notion that the importance of trade linkages affects the pattern of contagion in currency crises. Similarly, Eichengreen and Rose (1998) find that while both macroeconomic and trade channels play a role in conveying shocks internationally, trade linkages dominate. Forbes (2004) finds that firms with higher exposure to Asia and Russia experienced reduced equity returns during those countries' crises. However, Lahiri and Vegh (2003) find that central banks often actively resist devaluations during financial crises, shedding doubt on the "contagion through competitive devaluation" hypothesis.

\section{Contagion through Foreign Asset Exposure}

The most direct source of contagion on the financial side is through deterioration in a country's balance sheet because of capital losses on assets with international exposure. International cross-holdings of assets increased substantially in the run-up to the 2008 financial crisis. These cross-holdings are desirable in tranquil periods, as shocks are usually imperfectly correlated across countries, allowing international risk-sharing; Allen and Gale (2000). 
However, Allen and Gale also demonstrate that extreme shocks can lead to deterioration in balance sheet positions which can then spread across regions, the classic definition of contagion.

Exposure to contagion through this financial channel may have been exacerbated in the 2008 crisis because of the prevalence of holdings of exotic financial instruments; these were particularly vulnerable to capital losses in the wake of a general downturn. For instance, when the market price of United States asset-backed securities fell, European banks holding that paper, as well as related conduits and structured investment vehicles (SIVs), experienced losses. These losses then spread to the asset-backed commercial paper market, as the institutions holding these money-losing instruments then turned to that market for funds, initiating a decline in liquidity in that market as well; see Davis (2008).

Coudert and Gex (2008) argue that credit default swap (CDS) market activity is also prone to contagion, noting that that market had seen a large rise in correlations of asset prices since August 2007. This induces investors to respond to bad news about an individual asset or market with more concern about counterparty risk of related and seemingly unrelated assets. In a similar vein, Gros and Micossi (2008) note that many European banks found themselves exposed to foreign countries due to the activities of their affiliates on those countries. While their balance sheets were formally separate, these banks centralized their asset and liability management, ensuring that subsidiary financial difficulties would find their way to home country lending policies. 
Vulnerability to adverse external shocks may be exacerbated due to poor balance sheet positions. For example, Davis (2008) argues that leveraged investors increase the risk of market contagion, as they may be forced to sell in illiquid situations, feeding a "fire-sale" dynamic that forces down prices further and results in the need for even more selling. Adrian and Shin (2008) argue that mark-to-market practices exacerbate the severity of the impact of changes in prices and perceived risks on market liquidity.

As measures of direct financial exposure, Forbes and Chinn (2004) use the ratio of total bank lending and foreign direct investment to a given country as a share of GDP. Ehrmann and Fratzscher (2009) use all bilateral stocks of assets and liabilities for foreign direct investment, portfolio investment and debt, and loans, as a share of GDP.

Empirical evidence confirms the existence of "shift-contagion" in financial markets. For example, Calvo and Reinhart (1996) find an increase in the correlation on returns in Asian and Latin American equity and bond markets following the Mexican peso crisis. Similarly, Baig and Goldfajn (1999) find evidence of increased correlation in asset returns in emerging markets following the 1997 Asian financial crisis.

\section{Contagious "Sudden Stops" in International Credit}

A number of studies [e.g. Davis (2008)], argue that the international interbank market may be a source of contagion and the global transmission of shocks. These markets typically lack collateral, and moral hazard is often introduced through implicit government guarantees of liquidity. This leads banks to conduct business in this market under conditions of low liquidity and poor information. As such, when credit disruptions affect particular banks, other banks 
often respond by rationing extensions of credit (rather than stiffening borrowing terms). The market can then seize up, with the result that international extensions of credit cease as in the Asian Financial crisis of 1997. In that crisis, weakly-capitalized Japanese banks immediately canceled credit lines of as much as 10 percent of GDP [Reisen (2008)].

The notion that linkages may exist through mutual dependence on foreign creditors is not new. Kaminsky and Reinhart (2000) divide borrowing countries into one set that predominantly borrows from Japanese banks and another that predominantly borrows from American banks. They find that once a number of countries in a given cohort exhibit crisis characteristics, the unconditional probability that an unaffected country in that cohort will also fall into crisis increases dramatically. Caramazza, et al (2000) also examine exposure to a common creditor, measured as the share of a country's borrowing from the country that lent most to the ground zero country, the importance of the borrower for that creditor country, and the product of these two measures, indicating mutual importance. They confirm that exposure to a common creditor is a significant source of contagion. Van Rijckeghem and Weder (2001) they develop and indicator of competition for funds, which measures the overall similarity between the borrowing patterns of the country in question and the ground zero country, using a methodology analogous to the measure of the intensity of trade competition with the ground zero country used in the literature cited above.

Similarly, Peek and Rosengren (1997) examine the case of the Japanese banking crisis, and find that disruptions to banking "parents" had an adverse impact on their lending through subsidiaries in the United States. They conclude that there may well be a role for contagion for 
financial linkages over and above that identified for trade linkages, and indeed, that some of the contagion previously identified as attributable to trade linkages may actually stem from financial linkages, as the two are highly correlated in the data. However, in practice it has proven difficult to empirically disentangle contagion due to trade linkages from that attributable to financial linkages, as countries that are closely linked in one dimension tend to also be linked in the other [e.g. Kaminsky and Reinhart (2002)].

In addition, it should be noted that not all potential crises actually metastasize into serious international financial crises. As discussed by Kaminsky, Reinhart and Vegh (2003), there have been a number of potentially major financial crises (such as the 1999 Brazilian devaluation and the 2001 Argentine default) that did not have dramatic international implications in practice. They note that one common distinction between cases where domestic financial crises did and did not lead to international spillovers was whether or not there were other borrowers exposed to a common leveraged creditor. These common leveraged creditors helped to foster contagion, as difficulties experienced in one borrowing country led to deteriorated bank balance sheet positions. In that sense, they reconcile the absence of contagion with a "fundamental," namely the lack of a common creditor to spread the shock internationally.

As the case of the "common competitor" channel for trade exposure, the "common creditor" channel is likely to be less relevant in the current crisis, where the downturn centered in the world's largest debtor, striking major creditors across the globe. As such, we concentrate below on the channel of financial exposure through direct holdings of foreign assets. 
Finally, while the literature has been generally upbeat about the possibilities of successful early warning models, there are results that foreshadow the limited usefulness for contagion-type linkages that we search for in this paper. For example, Kaminsky and Reinhart (2002) find no evidence that knowing that a single crisis is occurring somewhere in the world raises the probability of a future crisis elsewhere. However, they do find predictive power for "systemic" crises, where one-half or more of the countries studied are having a crisis, to predict an increased risk of crisis in the examined country. They conclude that the contagion relationship is "highly nonlinear" and difficult to estimate precisely.

Our reading of the literature leads to believe that contagious responses along both real and financial channels are both theoretically possible and empirically plausible. Accordingly, we now search for evidence of contagion in the 2008 crisis, using the measures suggested in the literature insofar as possible.

\section{The Sample of Data}

We are interested in examining a broad cross-section of countries and territories. ${ }^{3}$ We wish to include all the countries that have been dramatically affected by the crisis as well as a number of other countries that have not been affected as badly (as controls). Since the incidence of the crisis was notable among high-income countries, we include all of them as well as a large number of developing countries. In particular, we examine all countries with real GDP per capita of at least $\$ 10,000$ in 2003 . To this set of countries, we add those with real GDP per capita of at least $\$ 4,000$ and a population of at least one million. ${ }^{4}$ After eliminating 
countries with missing data, we are left with a sample of 85 countries; their names are tabulated in Appendix Table A1.

\section{Identifying Cross-sectional Differences in Crisis Severity}

Identifying the incidence of a financial crisis (currency, asset, banking, or other) across countries is no simple matter, let alone determining its severity (e.g. Berg, et al, 2004). Any reasonable methodology should take into account the fact that potentially serious measurement error is inherently present.

Ours is a non-structural approach. In particular, we consider four observable indicators of the crisis, and model the incidence and severity of the crisis as being a latent variable that is manifest through these variables. When measuring these manifestations of the crisis, we restrict ourselves insofar as possible to data from 2008 (we sometimes use data from early 2009).

Our first measure of the 2008 crisis is real GDP growth over 2008, as estimated by the Economic Intelligence Unit (EIU) in early March 2009. ${ }^{6}$ We also consider a broad range of financial variables covering stocks, bonds, and international finance. Above and beyond growth, we include: 1) the percentage change in a broad measure of the national stock market over the 2008 calendar year (collected from national sources); 2) the percentage change in the SDR (multilateral) exchange rate over 2008 (measured as the domestic currency price of a Special Drawing Right and taken from the IMF's International Financial Statistics); and 3) the change in the country credit rating from Institutional Investor magazine. The latter are ratings created by Institutional Investor that rank 177 countries on a scale between 0 and 100 where 
100 represents the least likelihood of default (as of March 2009, Switzerland was the most highly rated country with a score of 94.0, while Zimbabwe brought up the rear at 4.6). ${ }^{7}$ Institutional Investor publishes these rankings biannually in March and September; we use the change between March 2008 and March 2009. ${ }^{8}$ We also use an analogue from Euromoney for sensitivity analysis. Our four measures of the consequences/manifestations of the crisis are presented for thirty countries in Table 1, sorted by the size of the 2008 stock market decline.

\section{Linking Incidence and Causes with the MIMIC Model}

Our primary interest is in linking crisis incidence to its causes. To avoid endogeneity issues and to stay within the setting of an early warning model, we restrict ourselves to data from 2006 and earlier for our crisis causes. We link 2006 (and earlier) causes of the crisis with 2008 measures of its intensity using a Multiple Indicator Multiple Cause (MIMIC) model.

The MIMIC model was introduced to econometrics by Goldberger (1972); see also Aigner et al (1984) and Gertler (1988). The model consists of two sets of equations:

$$
\begin{gathered}
y_{i, j}=\beta_{j} \xi_{i}+v_{i} \\
\xi_{i}=\gamma_{k} x_{i, k}+\zeta_{i}
\end{gathered}
$$

where: $y_{i, j}$ is an observation on crisis indicator $j$ for country $i, x_{i, k}$ is an observation for potential crisis cause $k$ for country $i ; \xi_{i}$ is a latent variable representing the severity of the crisis for country $i ; \beta$ and $\gamma$ are vectors of coefficients, and $v$ and $\zeta$ are well-behaved disturbances. ${ }^{9}$ Equation (1) links J consequences and manifestations of the crisis (denoted by y) to the 
unobservable measure of crisis severity. In practice, we model this measurement equation using our ( $J=4)$ indications of the crisis (the 2008 national changes in: a) real GDP, b) the stock market, c) the credit rating, and d) the exchange rate). The second equation models the determination of the crisis as a function of $K$ causes ( $x^{\prime} s$, dated 2006 or earlier).

By substituting (2) into (1), one derives a model which is no longer a function of the latent variable $\xi$. This MIMIC model is a system of J equations with right-hand-sides restricted to be proportional to each another. These proportionality restrictions constrain the structure to be a "one-factor" model of the latent variable; with the addition of normalization, they achieve identification of the parameters in (1) and (2). One of the features of the MIMIC model is that it explicitly incorporates measurement error about a key variable - the incidence and severity of the crisis - in a non-trivial and plausible way. Indeed, this is one of the chief attractions of the MIMIC model to us. ${ }^{10}$

We estimate our MIMIC models in STATA with GLLAMM; Rabe-Hesketh et al (2004a, b) provide further details. The iterative estimation technique begins with adaptive quadrature which is followed by Newton-Raphson. ${ }^{11}$ We normalize and achieve identification by imposing a factor loading of unity on the stock market change. ${ }^{12}$

In RS, we examined more than eighty possible national determinants of the crisis suggested by the literature. We found that only two variables worked consistently well; the natural logarithm of 2006 real GDP per capita, and the percentage change in the stock market between 2003 and 2006. We include both as controls in all of our analysis, as well as the log of 2006 population. 
In Table 2 we report MIMIC estimates of $\gamma$ when we include our three control variables as potential causes in (2); we use our four default indicators as measures of the crisis. We also provide sensitivity analysis in Table 2 . First, we replace the Institutional Investor country credit rating with its analogue from Euromoney. Secondly, we drop the exchange rate indicator from our four manifestations of the crisis, since some countries use the exchange rate as a tool of monetary policy. Thirdly, we replace our 2008 growth estimate with the 2009 estimate made by the Economist Intelligence unit in September 2009. Our results consistently indicate that size has no significant impact on the incidence of crises across countries, while income has a significantly negative impact. Further, countries that experienced larger stock market rises between 2003 and 2006 also experienced more severe crises in 2008 . These intuitive results mirror those of RS.

\section{Contagion via International Financial Linkages}

We now add each of the potential financial linkages suggested by our literature review to the default MIMIC model of Table 2 one by one, and report the estimates in Table 3. Throughout, we consistently retain size, income and the 2003-6 stock market rise as causes ( $\left.x^{\prime} s\right)$. The coefficients tabulated in Table 3 are taken from our default MIMIC model augmented by the cause recorded in the extreme left-hand side; four crisis indicators are used to model $\xi$, while size, income, and the stock market rise are included as causes ( $x^{\prime}$ s), but not recorded so as to conserve on space. Standard errors are recorded in parentheses, and coefficients significantly different from zero at the .05 (.01) level are marked by one (two) asterisk(s). 
We also include in Table 3 four other columns of sensitivity analysis. Each perturbs the methodology in some way so as to show the sensitivity of our results. The first column to the right of the default uses the Euromoney country credit ranking in place of that from Institutional Investor, while the next drops the exchange rate change as a crisis indicator. The two additional columns at the right-hand side both drop the size control (which is rarely statistically significant) and replace it with either the current account or net foreign assets, both measured as percentages of GDP.

The first row of Table 3 adds to our default specification the share of external assets (taken from the IMF's 2006 CPIS data set) that are held in the United States. At the end of 2006, Canada held a total of US\$633.05 externally in total portfolio investments, of which some US\$325.84 billion (or 51.5\%) were held in the United States. Canada was thus more heavily exposed to American financial risk than say the UK, which held only $26.6 \%$ of its external financial assets in America. The top left cell in Table 3 is the $(\nu)$ coefficient for the marginal effect of the share of foreign assets held in the United States on the latent variable of crisis incidence $(\xi) .{ }^{13}$ The coefficient is positive and significantly different from zero at the .05 level; countries with more exposure to American financial assets seem to have experienced less intense crises. Further, this result seems to be insensitive to the exact econometric specification of the statistical model.

The result that countries with greater exposure to American assets experienced less severe crises may seem initially surprising, especially given the wide-spread chatter in the popular press about toxic American assets. However, it seems to be present in the data and is 
not a mere statistical illusion. Figure 1 provides simple scatter-plots of our four manifestations of the crisis graphed against the share of external assets held in the United States. Countries that had larger shares of their 2006 foreign wealth in America seem systematically to have experienced smaller stock market declines in $2008 .^{14}$

It seems reasonable to view the USA as the epicenter of the crisis, but other candidates exist. In Western Europe, a number of countries have experienced particularly severe downturns, including the UK, Germany and Spain. Two large economies in East Asia - Japan and Korea - are also reasonable candidates for the dubious distinction of "crisis epicenter." Finally, a number of smaller countries in Europe - Iceland, Ireland, the Ukraine, and the three Baltic states of Estonia, Latvia, and Lithuania - have also had dramatic contractions (we refer to these as the "small crisis" countries). Accordingly, the next six rows of Table 3 replace the fraction of external assets held in the United States with analogous measures for e.g., the fraction of foreign assets held in the UK (Germany, Japan, etc). However, none of these coefficients is statistically distinguishable from zero.

Thus far, we have considered only the fraction of total foreign assets held in the United States (and our other candidate epicenters). However, not all assets are created equal and the 2008 crisis is sometimes particularly closely linked with poor loans, which were often securitized and sold off as debt. Accordingly, we also consider the share of total external debt (both total and long-term debt) held in various countries; our results are again tabulated in Table 3. Narrowing our focus to these sub-sets of external financial exposure only seems to 
blur the result further, though greater exposure to the United States still seems to be associated with somewhat less intense crises (as always, holding other things constant).

We explore our financial linkages further by taking advantage of a data set unique to America, the Treasury International Capital (TIC) system, which records foreign holdings of various American assets by residents of foreign countries. ${ }^{15}$ This data set only includes American securities, so we normalize e.g., Canadian holdings of American assets by Canadian GDP (for the CPIS data set, we are able to express Canadian holdings of American assets as a share of total external Canadian assets). However, when we add these international financial linkages to the United States to our default MIMIC model, we find only statistically weak and sensitive results; six types of American assets are included in Table 3.

Our last pair of financial linkages is taken from the World Bank's Global Development Finance data set. Both refer to the currency composition of public and publicly-guaranteed (PPG) debt; we have shares of PPG debt denominated in both yen and US\$. We try both of these series in the final rows of Table 3. The higher the share of debt denominated in yen, the more intense the crisis seems to be, though this result is not usually different from zero at standard levels of statistical significance. By way of contrast, countries with higher fractions of dollar debt had less intense crises. ${ }^{16}$ Figure 2 presents scatter-plots of the four crisis manifestations graphed against the fraction of PPG debt denominated in dollars, and shows evidence of weak positive correlations.

To summarize, there is little strong evidence of an international financial linkage which might have allowed a crisis centered initially in America to spread to other countries 
contagiously. ${ }^{17}$ Despite looking across a number of different potential measures of international financial linkage as well as different potential epicenters of the 2008 crisis, evidence of contagion seems weak. If anything, it appears that countries with closer financial ties to the United States seem to have experienced less intense crises.

\section{Trade Linkages}

The evidence presented in Table 3 covers a number of different financial channels that might link the epicenter of the 2008 crisis to other countries. But the channel through which the crisis was transmitted might have been real, not financial. Accordingly, we now search for evidence that the channel for contagion was real, and can be measured through bilateral trade exposure.

Table 4 is an analogue to Table 3 but examines trade linkages instead of financial linkages. Specifically, we include the fraction of total 2006 exports that a country sends to the United States as a fraction of its total exports. Canada, Mexico, and Haiti each sent over $80 \%$ of their exports to the United States while Cyprus, Qatar, and Macedonia sent less than $1 \%$ of their exports to America. ${ }^{18}$ The former three countries might logically have expected their trade to suffer more than the latter in the event of an American recession. Does this measure of export vulnerability help explain relative crisis performance? The results in the top row indicate that the answer is affirmative; greater export dependence on the United States leads systematically to less intense financial disruptions. Figure 3 provides the relevant graphical evidence, scattering the four crisis manifestations against export dependence on America. This relationship does not characterize other potential epicenters of the crisis; there is no systematic 
strong evidence that export dependence on any except the small crisis countries matters. However, countries with substantial exports to the small crisis countries - especially those in the Baltics - are systematically associated with more intense crises. ${ }^{19}$

The top half of table 4 focuses on export exposure to the United States (and other potential epicenters of the 2008 crisis). The bottom half is analogous, but substitutes two-way trade - the sum of bilateral exports and imports, divided by total exports and imports - in place of exports. However, this does not change the results substantively. Countries that traded more with the USA in 2006 seemed to experience less intense crises in 2006; the visual analogue is graphed in Figure $4 .^{20}$

\section{Including both Real and Financial Linkages Simultaneously}

Thus far, the analysis has focused on searching for a single transmission channel for international crisis contagion. However, there may be more than one channel in which a crisis can spread contagiously. Accordingly we include a number of different transmission mechanisms simultaneously in Table 5.

In Table 5a, we tabulate coefficient estimates for a number of different causes which we include in the MIMIC model simultaneously. Above and beyond our three default causes (2006 size, 2006 income, and the 2003-2006 stock market rise), we include four channels of contagion. Two are financial: the fraction of external assets held in American securities and the fraction of PPG debt denominated in dollars. The other two are real: exports to both the United States and the small crisis countries. As always, we provide a number of different 
perturbations of the model to check on the robustness of our findings. Table $5 b$ is the analogue to Table 5 a in every way, but substitutes trade with America in place of exports to America.

The results in Table 5 are weak; almost none of the channels for contagion seem to have statistically discernible effects on crisis intensity. The only exception is the real channel to the United States; countries that proportionately either exported more to or (especially) traded more with the United States in 2006 experienced less severe 2008 crises. However, there is little evidence of contagion spreading through a financial channel.

\section{Summary and Conclusion}

In this short paper, we model the causes of the international financial crisis that hit much of the world in 2008 . We use a flexible econometric methodology which takes into account the facts that the intensity of the crisis varies across countries, is only imperfectly measured, and may have multiple causes and manifestations. We rely on our previous work to model the national causes of the crisis, using data from 2006 and earlier. Above and beyond these national causes, we search for evidence that the 2008 financial crisis spread contagiously from the United States to other countries, via a number of both financial and real channels that might have transmitted the crisis from its epicenter. While we believe that it is natural to model the origins of the crisis as American, we also test for six other potential epicenters.

Despite our broad-ranging search, we are unable to find strong evidence of contagion. Indeed, countries that were more exposed to the United States -- those that held disproportionate amounts of American securities or depended heavily on exports to the United States - seem if anything to have experienced smaller crises, holding other factors constant. 
Overall though, we find remarkably little evidence that the intensity of the crisis across countries can be easily modeled using quantitative techniques and standard data that is either country-specific or links countries to the source of the crisis. This negative finding in the crosssection is powerful since we know, with the benefit of hindsight, both the approximate timing and the epicenter of the 2008 crisis. It makes us skeptical of the ability of "early warning systems" which must be able to predict the incidence of future crises across both countries and time. 


\section{References}

Adrian, T., and Hyun song Shin (2008) "Liquidity and Financial Contagion" Financial Stability Review Banque de France, February 2008.

Aigner, Dennis J., Cheng Hsiao, Arie Kapetyn, and Tom Wansbreek (2004) "Latent Variable Models in Econometrics" in Handbook of Econometrics II (Z. Griliches and M.D. Intriligator, eds) Elsevier Science, Amsterdam, 1321-1393.

Allen, Franklin and Douglas Gale (2000) "Financial Contagion" Journal of Political Economy 108(1), 1-33.

Baig, Taimur, and Ilan Goldfajn (1999) "Financial Market Contagion in the Asian Crisis" International Monetary Fund Staff Papers 46(2) June, 167-195.

Bekaert, Geert, Campbell R. Harvey, Angela Ng (2005) “Market Integration and Contagion” Journal of Business 78(1,) 39-69.

Berg, Andrew, Eduardo Borensztein, and Catherine Patillo (2004) "Assessing Early Warning Systems: How Have They Worked in Practice?" IMF Working Paper no. WP/04/52, March.

Breusch, Trevor (2005) "Estimating the Underground Economy Using MIMIC Models" ANU working paper.

Calvo, Sarah, and Carmen M. Reinhart (1996) "Capital Flows to Latin America: Is There Evidence of Contagion Effects?" in G. Calvo, M. Goldstein, and E. Hochreiter, eds., Private Capital Flows to Emerging Markets (Institute for International Economics: Washington D.C.).

Caramazza, Francesco, Luca A. Ricci, and Ranil Salgado, (2000), "Trade and Financial Contagion in Currency Crises," IMF Working Paper No. 00/55, March.

Coudert, Virginie and Mathieu Gex (2008) "Stormy Weather in the Credit Default Swap Market" in Felton A. and Reinhart, C. M. eds., The First Global Financial Crisis of the $21^{\text {st }}$ Century Part II June - December 2008, VoxEU.org, 13 October 2008.

Davis, E. Philip (2008) "Liquidity, financial Crises and the Lender of Last Resort - How much of a departure is the Sub-Prime Crisis?" in Bloxham P. and Kent C. Eds., Lessons from the Financial Turmoil of 2007 and 2008 Reserve Bank of Australia Conference, H. C. Coombs Centre for Financial Studies, 14-15 July, 2008.

Edwards, Sebastian, (2002), “Contagion” The World Economy 23(7), 873-900. 
Ehrmann, Michael, and Marcel Fratzscher, (2009), "Global Financial Transmission of Monetary Policy Shocks," forthcoming, Oxford bulletin of Economics and Statistics.

Eichengreen, Barry, Ashoka Mody, Milan Nedeljkovic, and Lucio Sarno (2009) "How the Subprime Crisis Went Global: Evidence from Bank Credit Default Swap Spreads, NBER Working Paper \#14904.

Eichengreen, Barry and Andrew K. Rose (1998) "Contagious Currency Crises: Channels of Conveyance" in T. Ito and A. Krueger, eds., Changes in Exchange Rates in Rapidly Developing Countries University of Chicago Press, 29-55.

Eichengreen, Barry, Andrew K. Rose and Charles Wyplosz (1996) "Exchange Market Mayhem: The Antecedents and Aftermath of Speculative Attacks" Economic Policy 10(21), 251-312.

Forbes, Kristen J., (2002), “Are Trade Linkages Important Determinants of Country Vulnerability to Crises?," in S. Edwards and J. Frankel, eds., Preventing Currency Crises in Emerging Markets, University of Chicago Press, Chicago, 77-124.

Forbes, Kristen J., (2004), "The Asian Flu and the Russian Virus: The International Transmission of Crises in Firm-Level Data," Journal of International Economics, 63, 59-92.

Forbes, Kristen J., and Menzie D. Chinn, (2004), "A Decomposition of Global Linkages in financial Markets Over Time," Review of Economics and Statistics, 86(3), August, 705-722.

Forbes, Kristen J. and Roberto Rigobon, (2001) "Measuring contagion: Conceptual and Empirical Issues" in S. Claessens and K. J. Forbes, eds., International Financial Contagion, MIT Press, New York, 43-66.

Forbes, Kristen J. and Roberto Rigobon (2002) “No Contagion, Only Interdependence: Measuring Stock Market Co-Movements" Journal of Finance, 57(5), 2223-2261.

Gerlach, Stefan and Frank Smets (1995) “Contagious Speculative Attacks" European Journal of Political Economy 11(1), 45-63.

Gertler, Paul J. (1988) "A Latent Variable Model of Quality Determination” Journal of Business and Economic Statistics 6, 97-107.

Glick, Reuven, and Andrew K. Rose (1999) "Contagion and Trade: Why are Currency Crises Regional?" Journal of International Money and Finance 18, 603-617.

Goldberger, Arthur S. (1972) "Structural Equation Methods in the Social Sciences" Econometrica, 40, 979-1001. 
Gros, Daniel, and Stefano Micossi (2008) "Crisis Management Tools for the Euro Area" " in Felton A. and Reinhart, C. M. eds., The First Global Financial Crisis of the $21^{\text {st }}$ Century Part II June - December 2008, VoxEU.org, 30 September, 2008.

Huh, Chan and Kenneth Kasa (2001) "A Dynamic Model of Export Competition, Policy Coordination, and Simultaneous Currency Collapse" Review of International Economics 9(1), 6880 .

Kaminsky, Graciela L., Saúl Lizondo, and Carmen M. Reinhart (1998) "Leading Indicators of Currency Crises" International Monetary Fund Staff Papers, 45(1), 1-48.

Kaminsky, Graciela and Carmen M. Reinhart (2000) "On Crises, Contagion, and Confusion" Journal of International Economics 51, 145-168.

Kaminsky, Graciela L., Carmen M. Reinhart, and Carlos A. Vegh (2003) "The Unholy Trinity of Financial Contagion" Journal of Economic Perspectives 17(4), 51-74.

Lahiri, Amartya, and Carlos Vegh (2003) "Delaying the Inevitable: Optimal Interest Rate and BOP Crises, Journal of Political Economy Spring(1), 1-62.

Peek, Joe and Eric S. Rosengren (1997) "The International Transmission of Financial Shocks: The Case of Japan" American Economic Review 87(4), 495-505.

Rabe-Hesketh, Sophia, Anders Skrondal, and Andrew Pickles (2004a) "Generalized Multilevel Structural Equation Modeling" Psychometrika 69 (2), 167-190.

Rabe-Hesketh, Sophia, Anders Skrondal, and Andrew Pickles (2004b) "GLLAMM Manual” UC Berkeley Biostatistics Working Paper 160.

Reisen, Helmut (2008) "The Fallout from the Global Credit Crisis: Contagion - Emerging Markets Under Stress" in Felton A. and Reinhart, C. M. eds., The First Global Financial Crisis of the $21^{\text {st }}$ Century Part II June - December 2008, VoxEU.org.

Rose, Andrew K. and Mark. M. Spiegel (2009) "Cross-Country Causes and Consequences of the 2008 Crisis: Early Warning” CEPR Discussion Paper \#7354. 
Table 1: Crisis Manifestations (30 countries, sorted by 2008 Stock Market Decline)

\begin{tabular}{|c|c|c|c|c|}
\hline & $\begin{array}{c}\text { \% Change in Stock } \\
\text { Market, } 2008\end{array}$ & $\begin{array}{c}\text { \% Change in SDR } \\
\text { Exchange Rate, } \\
2008\end{array}$ & $\begin{array}{c}\text { Change in } \\
\text { Institutional } \\
\text { Investor Rating }\end{array}$ & 2008 Growth \\
\hline Iceland & -90 & 90 & -32.5 & -4.7 \\
\hline Bulgaria & -79.7 & 1 & -6.6 & 5.4 \\
\hline Cyprus & -77.2 & 3.1 & 0.8 & 3.5 \\
\hline Ukraine & -74.3 & 48.7 & -12.1 & 2.1 \\
\hline Macedonia & -72.8 & 1.9 & 0 & 4.9 \\
\hline Romania & -70.5 & 12.5 & -5.9 & 7.7 \\
\hline Slovenia & -67.5 & 3.1 & 0.5 & 4 \\
\hline Croatia & -67.1 & 0.8 & -3.7 & 2.2 \\
\hline Ireland & -66.1 & 3.1 & -7.8 & -2.8 \\
\hline Lithuania & -66 & 1.3 & -7.9 & 3.7 \\
\hline Kazakhstan & -65.7 & -2.1 & -8.9 & 3.2 \\
\hline Greece & -65.5 & 3.1 & -4.6 & 3 \\
\hline China & -65.2 & -8.8 & -2.4 & 9 \\
\hline Russia & -64.9 & 16.7 & -4.8 & 5.6 \\
\hline Estonia & -63 & 1.7 & -9.4 & -2.8 \\
\hline Austria & -61.2 & 3.1 & -4.6 & 1.6 \\
\hline Peru & -59.8 & 2.1 & 1.1 & 9.8 \\
\hline Luxembourg & -59.5 & 3.1 & -2.6 & 0.6 \\
\hline Egypt & -57.5 & -3.1 & -0.8 & 7.2 \\
\hline Saudi Arabia & -56.5 & -2.5 & -0.4 & 4.2 \\
\hline Latvia & -55.1 & -0.3 & -8.3 & -4.6 \\
\hline Belgium & -53.8 & 3.1 & -3.8 & 1.1 \\
\hline Finland & -53.4 & 3.1 & -2.6 & 1.4 \\
\hline Hungary & -53.2 & 6.1 & -7.6 & 0.4 \\
\hline Norway & -52.6 & 26.1 & -2.1 & 1.5 \\
\hline Turkey & -52.4 & 27.6 & -3 & 1.5 \\
\hline Netherlands & -52.3 & 3.1 & -2.5 & 2 \\
\hline Czech Rep & -52.2 & 4.3 & -1.7 & 3.5 \\
\hline Portugal & -51.2 & 3.1 & -4.3 & 0 \\
\hline Poland & -51.1 & 18.6 & -1.5 & 4.8 \\
\hline
\end{tabular}


Table 2: Default Model: Only Control Variables

\begin{tabular}{|l|c|c|c|c|}
\hline Control & Default & $\begin{array}{c}\text { Drop Exchange } \\
\text { Rate Cause }\end{array}$ & $\begin{array}{c}\text { Euromoney, } \\
\text { not II }\end{array}$ & $\begin{array}{c}\mathbf{2 0 0 9} \text { Growth, } \\
\text { not 2008 }\end{array}$ \\
\hline Log (2006 Population) & -1.2 & -1.2 & -1.2 & -1.1 \\
& $(1.1)$ & $(1.1)$ & $(1.1)$ & $(1.1)$ \\
\hline Log (2006 real GDP p/c) & $-12.8^{* *}$ & $-12.8^{* *}$ & $-12.9^{* *}$ & $-12.9^{* *}$ \\
& $(2.4)$ & $(2.5)$ & $(2.4)$ & $(2.4)$ \\
\hline 2003-2006 Stock Market Rise & $-10.2^{* *}$ & -10.2 & $-10.1^{* *}$ & $-10.1^{* *}$ \\
& $(2.0)$ & $(2.0)$ & $(2.0)$ & $(2.0)$ \\
\hline
\end{tabular}

Coefficients, with standard error displayed in parentheses. Coefficients significantly different from zero at .05 (.01) significance level marked by one (two) asterisk(s). Each column represents MIMC estimation on cross-section. Default: 4 consequences (2008 change in Stocks, 2008 Growth, 1-year change in Institutional rating, 2008 Exchange Rate change), fixed loading on stocks. Adaptive quadrature estimation; 85 observations. 
Table 3: Adding Financial Linkages, One by One

\begin{tabular}{|c|c|c|c|c|c|c|}
\hline $\begin{array}{l}\text { Linkage } \\
\text { (2006) }\end{array}$ & $\begin{array}{c}\text { Exposure } \\
\text { to }\end{array}$ & Default & $\begin{array}{c}\text { Drop } \\
\text { Exchange } \\
\text { Rate Cause }\end{array}$ & $\begin{array}{c}\text { Euromoney, } \\
\text { not II }\end{array}$ & $\begin{array}{c}\text { Condition on } \\
\text { C/acc (\%GDP), } \\
\text { not size }\end{array}$ & $\begin{array}{c}\text { Condition on } \\
\text { NFA (\%GDP), } \\
\text { not size }\end{array}$ \\
\hline CPIS Asset Share & USA & $\begin{array}{l}.27^{*} \\
(.10)\end{array}$ & $\begin{array}{l}.36^{* *} \\
(.09)\end{array}$ & $\begin{array}{l}.29^{*} \\
(.10)\end{array}$ & $\begin{array}{l}.19^{*} \\
(.10)\end{array}$ & $\begin{array}{l}.23^{*} \\
(.10)\end{array}$ \\
\hline CPIS Asset Share & UK & $\begin{array}{l}-.28 \\
(.14)\end{array}$ & $\begin{array}{l}-.15 \\
(.16)\end{array}$ & $\begin{array}{c}6 \mathrm{e}-6 \\
(.00003)\end{array}$ & $\begin{array}{c}-.28 * * \\
(.10)\end{array}$ & $\begin{array}{l}.0002 \\
(.0002)\end{array}$ \\
\hline CPIS Asset Share & Germany & $\begin{array}{l}-.30 \\
(.38)\end{array}$ & $\begin{array}{l}-.68 \\
(.38)\end{array}$ & $\begin{array}{l}-.36 \\
(.39)\end{array}$ & $\begin{array}{l}-.25 \\
(.33)\end{array}$ & $\begin{array}{l}-.0007 \\
(.0006)\end{array}$ \\
\hline CPIS Asset Share & Japan & $\begin{array}{l}.26 \\
(.88)\end{array}$ & $\begin{array}{l}1.02 \\
(.95)\end{array}$ & $\begin{array}{l}.32 \\
(.91)\end{array}$ & $\begin{array}{c}.0003 \\
(.0007)\end{array}$ & $\begin{array}{l}.0003 \\
(.0007)\end{array}$ \\
\hline CPIS Asset Share & Spain & $\begin{array}{l}-.44 \\
(.75)\end{array}$ & $\begin{array}{l}-.70 \\
(.88)\end{array}$ & $\begin{array}{l}-.51 \\
(.76)\end{array}$ & $\begin{array}{l}-.0001 \\
(.0003)\end{array}$ & $\begin{array}{l}-.0002 \\
(.0005)\end{array}$ \\
\hline CPIS Asset Share & Korea & $\begin{array}{c}.16 \\
(1.97)\end{array}$ & $\begin{array}{l}-1.01 \\
(2.47)\end{array}$ & $\begin{array}{c}.19 \\
(1.98)\end{array}$ & $\begin{array}{l}-1.06 \\
(1.36)\end{array}$ & $\begin{array}{l}.0008 \\
(.002)\end{array}$ \\
\hline CPIS Asset Share & $\begin{array}{l}\text { Small } \\
\text { Crises }\end{array}$ & $\begin{array}{l}-.82 \\
(.62)\end{array}$ & $\begin{array}{l}-1.24 \\
(.73)\end{array}$ & $\begin{array}{l}-.87 \\
(.63)\end{array}$ & $\begin{array}{l}-.43 \\
(.44)\end{array}$ & $\begin{array}{l}.0001 \\
(.0005)\end{array}$ \\
\hline CPIS Debt Share & USA & $\begin{array}{l}.19^{*} \\
(.09)\end{array}$ & $\begin{array}{l}.28 * * \\
(.08)\end{array}$ & $\begin{array}{l}.21^{*} \\
(.09)\end{array}$ & $\begin{array}{l}.10 \\
(.09)\end{array}$ & $\begin{array}{l}.13 \\
(.09)\end{array}$ \\
\hline CPIS Debt Share & UK & $\begin{array}{l}-.01 \\
(.27)\end{array}$ & $\begin{array}{l}-.11 \\
(.28)\end{array}$ & $\begin{array}{l}-.02 \\
(.27)\end{array}$ & $\begin{array}{l}-.02 \\
(.24)\end{array}$ & $\begin{array}{l}-.0000 \\
(.0001)\end{array}$ \\
\hline CPIS Debt Share & Germany & $\begin{array}{l}-.35 \\
(.26)\end{array}$ & $\begin{array}{l}-.51 \\
(.27)\end{array}$ & $\begin{array}{l}-.39 \\
(.26)\end{array}$ & $\begin{array}{l}-.28 \\
(.23)\end{array}$ & $\begin{array}{l}-.000 \\
(.001)\end{array}$ \\
\hline CPIS Debt Share & Japan & $\begin{array}{l}.10 \\
(.92)\end{array}$ & $\begin{array}{l}.30 \\
(.99)\end{array}$ & $\begin{array}{l}.10 \\
(.95)\end{array}$ & $\begin{array}{c}.001 \\
(.001)\end{array}$ & $\begin{array}{l}.001 \\
(.001)\end{array}$ \\
\hline CPIS Debt Share & Spain & $\begin{array}{l}-1.02 \\
(.58)\end{array}$ & $\begin{array}{l}-.70 \\
(.71)\end{array}$ & $\begin{array}{l}-1.08 \\
(.59)\end{array}$ & $\begin{array}{c}.0002 \\
(.0004)\end{array}$ & $\begin{array}{l}.000 \\
(.002)\end{array}$ \\
\hline CPIS Debt Share & Korea & $\begin{array}{c}-.64 \\
(1.73)\end{array}$ & $\begin{array}{c}.15 \\
(1.76)\end{array}$ & $\begin{array}{c}-.62 \\
(1.73)\end{array}$ & $\begin{array}{l}-2.12 \\
(1.48)\end{array}$ & $\begin{array}{l}-1.71 \\
(1.35)\end{array}$ \\
\hline CPIS Debt Share & $\begin{array}{l}\text { Small } \\
\text { Crises }\end{array}$ & $\begin{array}{l}-.18 \\
(.61)\end{array}$ & $\begin{array}{l}-1.14 \\
(.74)\end{array}$ & $\begin{array}{l}-.22 \\
(.62)\end{array}$ & $\begin{array}{c}.09 \\
(.43)\end{array}$ & $\begin{array}{l}-.0004 \\
(.0007)\end{array}$ \\
\hline $\begin{array}{l}\text { CPIS Long Debt } \\
\text { Share }\end{array}$ & USA & $\begin{array}{c}-.64 \\
(1.26)\end{array}$ & $\begin{array}{l}.28 * * \\
(.09)\end{array}$ & $\begin{array}{l}.20^{*} \\
(.09)\end{array}$ & $\begin{array}{l}.11 \\
(.09)\end{array}$ & $\begin{array}{l}.14 \\
(.09)\end{array}$ \\
\hline $\begin{array}{l}\text { CPIS Long Debt } \\
\text { Share }\end{array}$ & UK & $\begin{array}{l}.06 \\
(.33)\end{array}$ & $\begin{array}{l}.03 \\
(.35)\end{array}$ & $\begin{array}{l}.06 \\
(.34)\end{array}$ & $\begin{array}{c}.11 \\
(.27)\end{array}$ & $\begin{array}{l}-.0000 \\
(.0002)\end{array}$ \\
\hline $\begin{array}{l}\text { CPIS Long Debt } \\
\text { Share }\end{array}$ & Germany & $\begin{array}{l}-.36 \\
(.26)\end{array}$ & $\begin{array}{l}-.51 \\
(.26)\end{array}$ & $\begin{array}{l}-.40 \\
(.26)\end{array}$ & $\begin{array}{l}-.30 \\
(.23)\end{array}$ & $\begin{array}{l}-.26 \\
(.22)\end{array}$ \\
\hline $\begin{array}{l}\text { CPIS Long Debt } \\
\text { Share }\end{array}$ & Japan & $\begin{array}{c}.81 \\
(1.10)\end{array}$ & $\begin{array}{c}.70 \\
(1.19)\end{array}$ & $\begin{array}{c}.77 \\
(1.13)\end{array}$ & $\begin{array}{l}-.04 \\
(.86) \\
\end{array}$ & $\begin{array}{l}.25 \\
(.86)\end{array}$ \\
\hline $\begin{array}{l}\text { CPIS Long Debt } \\
\text { Share }\end{array}$ & Spain & $\begin{array}{l}-.71 \\
(.60)\end{array}$ & $\begin{array}{l}-.40 \\
(.71)\end{array}$ & $\begin{array}{l}-.76 \\
(.61)\end{array}$ & $\begin{array}{l}-.11 \\
(.44)\end{array}$ & $\begin{array}{l}-.11 \\
(.48)\end{array}$ \\
\hline $\begin{array}{l}\text { CPIS Long Debt } \\
\text { Share }\end{array}$ & Korea & $\begin{array}{c}-.37 \\
(1.40)\end{array}$ & $\begin{array}{c}.43 \\
(1.42)\end{array}$ & $\begin{array}{c}-.35 \\
(1.41)\end{array}$ & $\begin{array}{c}-.57 \\
(1.21)\end{array}$ & $\begin{array}{l}-1.06 \\
(.91)\end{array}$ \\
\hline $\begin{array}{l}\text { CPIS Long Debt } \\
\text { Share }\end{array}$ & $\begin{array}{l}\text { Small } \\
\text { Crises }\end{array}$ & $\begin{array}{l}.15 \\
(.51)\end{array}$ & $\begin{array}{l}-.59 \\
(.72)\end{array}$ & $\begin{array}{l}.14 \\
(.51)\end{array}$ & $\begin{array}{c}-.01 \\
(1.03)\end{array}$ & $\begin{array}{l}-.0006 \\
(.0005)\end{array}$ \\
\hline
\end{tabular}




\begin{tabular}{|c|c|c|c|c|c|c|}
\hline $\begin{array}{l}\text { US TIC } \\
\text { Assets/GDP }\end{array}$ & USA & $\begin{array}{c}.19 \\
(1.39)\end{array}$ & $\begin{array}{c}-.04 \\
(1.40)\end{array}$ & $\begin{array}{c}.17 \\
(1.39) \\
\end{array}$ & $\begin{array}{c}.10 \\
(1.81)\end{array}$ & $\begin{array}{c}.42 \\
(1.61)\end{array}$ \\
\hline $\begin{array}{l}\text { US TIC } \\
\text { Equity/GDP }\end{array}$ & USA & $\begin{array}{c}1.01 \\
(3.96) \\
\end{array}$ & $\begin{array}{c}.37 \\
(3.99) \\
\end{array}$ & $\begin{array}{c}.95 \\
(3.97) \\
\end{array}$ & $\begin{array}{c}.87 \\
(4.14) \\
\end{array}$ & $\begin{array}{r}1.75 \\
(3.84) \\
\end{array}$ \\
\hline $\begin{array}{l}\text { US TIC Long } \\
\text { Debt/GDP }\end{array}$ & USA & $\begin{array}{c}.32 \\
(2.30) \\
\end{array}$ & $\begin{array}{c}-.18 \\
(2.35) \\
\end{array}$ & $\begin{array}{c}.28 \\
(2.31) \\
\end{array}$ & $\begin{array}{c}-.004 \\
(3.74) \\
\end{array}$ & $\begin{array}{c}.70 \\
(2.91) \\
\end{array}$ \\
\hline US TIC Debt/GDP & USA & $\begin{array}{c}.22 \\
(2.02) \\
\end{array}$ & $\mathrm{n} / \mathrm{a}$ & $\begin{array}{c}.16 \\
(2.03) \\
\end{array}$ & $\begin{array}{c}-.11 \\
(2.52) \\
\end{array}$ & $\begin{array}{c}.16 \\
(2.69) \\
\end{array}$ \\
\hline $\begin{array}{l}\text { US TIC } \\
\text { Treasuries/GDP }\end{array}$ & USA & $\begin{array}{c}3.77 \\
(12.14) \\
\end{array}$ & $\begin{array}{c}-1.42 \\
(12.48) \\
\end{array}$ & $\begin{array}{c}3.55 \\
(12.20) \\
\end{array}$ & $\begin{array}{l}-2.81 \\
(15.7) \\
\end{array}$ & $\begin{array}{c}6.42 \\
(12.86) \\
\end{array}$ \\
\hline $\begin{array}{l}\text { US TIC Long } \\
\text { Treasuries /GDP }\end{array}$ & USA & $\begin{array}{c}3.55 \\
(13.75) \\
\end{array}$ & $\begin{array}{c}-1.32 \\
(14.06) \\
\end{array}$ & $\begin{array}{c}3.34 \\
(13.80) \\
\end{array}$ & $\begin{array}{l}-4.48 \\
(15.7) \\
\end{array}$ & $\begin{array}{c}5.71 \\
(15.41) \\
\end{array}$ \\
\hline $\begin{array}{l}\text { \% PPG Debt in } \\
\text { Yen }\end{array}$ & Japan & $\begin{array}{l}-.33 \\
(.25)\end{array}$ & $\begin{array}{l}-.34 \\
(.25)\end{array}$ & $\begin{array}{l}-.33 \\
(.25)\end{array}$ & $\begin{array}{l}-.66^{* *} \\
(.10)\end{array}$ & $\begin{array}{c}-.58^{* *} \\
(.10) \\
\end{array}$ \\
\hline \% PPG Debt in \$ & USA & $\begin{array}{l}.21^{*} \\
(.10)\end{array}$ & $\begin{array}{l}.21^{*} \\
(.10)\end{array}$ & $\begin{array}{l}.22 * \\
(.10)\end{array}$ & $\begin{array}{l}.18^{* *} \\
(.06)\end{array}$ & $\begin{array}{l}.15^{*} \\
(.07) \\
\end{array}$ \\
\hline
\end{tabular}

Coefficients, with standard error displayed in parentheses. Coefficients significantly different from zero at .05 (.01) significance level marked by one (two) asterisk(s). Each cell represents MIMC estimation on cross-section.

Default: 4 consequences (2008 change in Stocks, 2008 Growth, 1-year change in Institutional rating, 2008 Exchange Rate change), fixed loading on stocks. Three control causes (log 2006 population, log 2006 real GDP p/c, 2003-06 stock market decline) included in all runs but not recorded. Adaptive quadrature estimation. 
Table 4: Adding Trade Linkages, One by One

\begin{tabular}{|c|c|c|c|c|c|c|}
\hline $\begin{array}{l}\text { Linkage } \\
(2006)\end{array}$ & $\begin{array}{c}\text { Exposure } \\
\text { to }\end{array}$ & Default & $\begin{array}{c}\text { Drop } \\
\text { Exchange Rate } \\
\text { Cause }\end{array}$ & $\begin{array}{c}\text { Euromoney, } \\
\text { not II }\end{array}$ & $\begin{array}{c}\text { Condition on } \\
\text { Trade (\%GDP), } \\
\text { not size }\end{array}$ & $\begin{array}{c}\text { Condition on } \\
\text { Exports (\%GDP), } \\
\text { not size }\end{array}$ \\
\hline Exports & USA & $\begin{array}{l}.28^{* *} \\
(.10)\end{array}$ & $\begin{array}{l}.32 * * \\
(.10)\end{array}$ & $\begin{array}{l}.29 * * \\
(.10)\end{array}$ & $\begin{array}{l}.31^{* *} \\
(.09)\end{array}$ & $\begin{array}{l}.30 * * \\
(.09)\end{array}$ \\
\hline Exports & UK & $\begin{array}{l}-.55 \\
(.35)\end{array}$ & $\begin{array}{l}-.53 \\
(.36)\end{array}$ & $\begin{array}{l}-.66 \\
(.35)\end{array}$ & $\begin{array}{l}-.51 \\
(.29)\end{array}$ & $\begin{array}{c}.0002 \\
(.0007)\end{array}$ \\
\hline Exports & Germany & $\begin{array}{l}-.42 \\
(.25)\end{array}$ & $\begin{array}{l}-.50 \\
(.26)\end{array}$ & $\begin{array}{l}-.44 \\
(.25)\end{array}$ & $\begin{array}{l}-.43 \\
(.25)\end{array}$ & $\begin{array}{l}-.45 \\
(.24)\end{array}$ \\
\hline Exports & Japan & $\begin{array}{l}-.26 \\
(.36)\end{array}$ & $\begin{array}{l}-.24 \\
(.37)\end{array}$ & $\begin{array}{l}-.26 \\
(.36) \\
\end{array}$ & $\begin{array}{l}-.27 \\
(.34)\end{array}$ & $\begin{array}{l}-.29 \\
(.35)\end{array}$ \\
\hline Exports & Spain & $\begin{array}{l}.18 \\
(.45)\end{array}$ & $\begin{array}{l}.22 \\
(.46)\end{array}$ & $\begin{array}{l}.18 \\
(.45)\end{array}$ & $\begin{array}{l}.16 \\
(.42)\end{array}$ & $\begin{array}{l}.14 \\
(.42)\end{array}$ \\
\hline Exports & Korea & $\begin{array}{l}.17 \\
(.55)\end{array}$ & $\begin{array}{c}.03 \\
(.56)\end{array}$ & $\begin{array}{l}.18 \\
(.55)\end{array}$ & $\begin{array}{l}-.0003 \\
(.0008)\end{array}$ & $\begin{array}{l}-.0002 \\
(.0002)\end{array}$ \\
\hline Exports & $\begin{array}{l}\text { Small } \\
\text { Crises }\end{array}$ & $\begin{array}{c}-1.02^{* *} \\
(.39)\end{array}$ & $\begin{array}{c}-1.11^{* *} \\
(.39)\end{array}$ & $\begin{array}{c}-1.04^{* *} \\
(.39)\end{array}$ & $\begin{array}{c}-.91 * * \\
(.35)\end{array}$ & $\begin{array}{c}-.89 * * \\
(.35)\end{array}$ \\
\hline Trade & USA & $\begin{array}{l}.38^{* *} \\
(.12)\end{array}$ & $\begin{array}{l}.43^{* *} \\
(.12)\end{array}$ & $\begin{array}{l}.38^{* *} \\
(.12)\end{array}$ & $\begin{array}{l}.39 * * \\
(.11)\end{array}$ & $\begin{array}{l}.38^{* *} \\
(.11)\end{array}$ \\
\hline Trade & UK & $\begin{array}{l}-.68 \\
(.50)\end{array}$ & $\begin{array}{l}-.58 \\
(.52)\end{array}$ & $\begin{array}{l}-.69 \\
(.51)\end{array}$ & $\begin{array}{l}-.67 \\
(.53)\end{array}$ & $\begin{array}{l}-.61 \\
(.57)\end{array}$ \\
\hline Trade & Germany & $\begin{array}{l}-.37 \\
(.36)\end{array}$ & $\begin{array}{l}-.45 \\
(.26)\end{array}$ & $\begin{array}{l}-.39 \\
(.26)\end{array}$ & $\begin{array}{l}-.37 \\
(.26)\end{array}$ & $\begin{array}{l}-.38 \\
(.25)\end{array}$ \\
\hline Trade & Japan & $\begin{array}{l}-.36 \\
(.44)\end{array}$ & $\begin{array}{l}-.36 \\
(.46)\end{array}$ & $\begin{array}{l}-.35 \\
(.44)\end{array}$ & $\begin{array}{l}-.40 \\
(.44)\end{array}$ & $\begin{array}{l}-.45 \\
(.45)\end{array}$ \\
\hline Trade & Spain & $\begin{array}{c}.21 \\
(.49)\end{array}$ & $\begin{array}{c}.21 \\
(.51)\end{array}$ & $\begin{array}{c}.20 \\
(.50)\end{array}$ & $\begin{array}{l}.20 \\
(.42)\end{array}$ & $\begin{array}{l}.22 \\
(.42)\end{array}$ \\
\hline Trade & Korea & $\begin{array}{l}.05 \\
(.74)\end{array}$ & $\begin{array}{l}-.20 \\
(.76)\end{array}$ & $\begin{array}{l}.06 \\
(.74)\end{array}$ & $\begin{array}{l}.05 \\
(.65)\end{array}$ & $\begin{array}{l}-.0003 \\
(.0004)\end{array}$ \\
\hline Trade & $\begin{array}{l}\text { Small } \\
\text { Crises }\end{array}$ & $\begin{array}{c}-1.29 * * \\
(.48)\end{array}$ & $\begin{array}{c}-1.39 * * \\
(.50)\end{array}$ & $\begin{array}{c}-1.30^{* *} \\
(.49)\end{array}$ & $\begin{array}{c}-1.11^{*} \\
(.41)\end{array}$ & $\begin{array}{c}.0003 \\
(.0003)\end{array}$ \\
\hline
\end{tabular}

Coefficients, with standard error displayed in parentheses. Coefficients significantly different from zero at .05 (.01) significance level marked by one (two) asterisk(s). Each cell represents MIMC estimation on cross-section.

Default: 4 consequences ( 2008 change in Stocks, 2008 Growth, 1-year change in Institutional rating, 2008 Exchange Rate change), fixed loading on stocks. Three control causes (log 2006 population, log 2006 real GDP p/c, 2003-06 stock market decline) included in all runs but not recorded. Adaptive quadrature estimation. 
Table 5a: Adding Financial and Real Linkages, Simultaneously (US Exports)

\begin{tabular}{|c|c|c|c|c|c|c|}
\hline $\begin{array}{l}\text { Control or } \\
\text { Linkage (2006) }\end{array}$ & $\begin{array}{c}\text { Exposure } \\
\text { to }\end{array}$ & Default & $\begin{array}{c}\text { Drop } \\
\text { Exchange } \\
\text { Rate Cause }\end{array}$ & $\begin{array}{c}\text { Euromoney, } \\
\text { not II }\end{array}$ & $\begin{array}{l}\text { Condition on } \\
\text { C/acc and } \\
\text { Trade (\%GDP) }\end{array}$ & $\begin{array}{l}\text { Condition on } \\
\text { NFA and } \\
\text { Exports } \\
\text { (\%GDP) }\end{array}$ \\
\hline $\begin{array}{l}\text { Log } 2006 \\
\text { (Population) }\end{array}$ & & $\begin{array}{l}-5.51^{*} \\
(2.06)\end{array}$ & $\begin{array}{c}-5.66^{* *} \\
(2.01)\end{array}$ & $\begin{array}{c}-5.59 * * \\
(2.06)\end{array}$ & $\begin{array}{c}-8.93^{* *} \\
(2.34)\end{array}$ & $\begin{array}{c}-7.03 * * \\
(2.41)\end{array}$ \\
\hline $\begin{array}{l}\log 2006 \\
\text { (GDP p/c) }\end{array}$ & & $\begin{array}{l}-6.68 \\
(9.48)\end{array}$ & $\begin{array}{l}-7.02 \\
(9.39)\end{array}$ & $\begin{array}{l}-6.75 \\
(9.46)\end{array}$ & $\begin{array}{c}-2.90 \\
(10.15)\end{array}$ & $\begin{array}{c}1.02 \\
(10.3)\end{array}$ \\
\hline $\begin{array}{l}\text { Stock Market } \\
\text { Rise, 2003-6 }\end{array}$ & & $\begin{array}{c}-5.04^{* *} \\
(1.95)\end{array}$ & $\begin{array}{c}-5.00 * * \\
(1.94)\end{array}$ & $\begin{array}{c}-5.03^{* *} \\
(1.94)\end{array}$ & $\begin{array}{c}-4.33^{* *} \\
(1.86)\end{array}$ & $\begin{array}{c}-6.48 * * \\
(2.06)\end{array}$ \\
\hline $\begin{array}{l}\text { CPIS Asset } \\
\text { Share, } 2006\end{array}$ & USA & $\begin{array}{c}.15 \\
(.14) \\
\end{array}$ & $\begin{array}{l}.15 \\
(.14) \\
\end{array}$ & $\begin{array}{c}.16 \\
(.14) \\
\end{array}$ & $\begin{array}{l}-.01 \\
(.15) \\
\end{array}$ & $\begin{array}{c}.08 \\
(.14) \\
\end{array}$ \\
\hline $\begin{array}{l}\text { \% PPG } 2006 \\
\text { Debt in \$ }\end{array}$ & USA & $\begin{array}{l}-.15 \\
(.20)\end{array}$ & $\begin{array}{l}-.14 \\
(.20)\end{array}$ & $\begin{array}{l}-.14 \\
(.20)\end{array}$ & $\begin{array}{l}-.01 \\
(.24)\end{array}$ & $\begin{array}{c}.07 \\
(.25)\end{array}$ \\
\hline $\begin{array}{l}\text { Exports } \\
2006\end{array}$ & $\begin{array}{l}\text { Small } \\
\text { Crises }\end{array}$ & $\begin{array}{l}-.71 \\
(.48)\end{array}$ & $\begin{array}{l}-.70 \\
(.47)\end{array}$ & $\begin{array}{l}-.72 \\
(.47)\end{array}$ & $\begin{array}{l}-.47 \\
(.47)\end{array}$ & $\begin{array}{l}-.98 \\
(.48)\end{array}$ \\
\hline $\begin{array}{l}\text { Exports } \\
2006\end{array}$ & USA & $\begin{array}{c}.35 \\
(.18) \\
\end{array}$ & $\begin{array}{c}.35 \\
(.18) \\
\end{array}$ & $\begin{array}{c}.34 \\
(.18) \\
\end{array}$ & $\begin{array}{l}.43^{*} \\
(.17)\end{array}$ & $\begin{array}{l}.41^{*} \\
(.18)\end{array}$ \\
\hline $\begin{array}{l}2006 \text { Current } \\
\text { Account } \\
\text { (\%GDP) }\end{array}$ & & & & & $\begin{array}{l}.80 \\
(.40)\end{array}$ & \\
\hline $\begin{array}{l}2006 \text { Trade } \\
\text { (\%GDP) }\end{array}$ & & & & & $\begin{array}{l}-.15 \\
(.10)\end{array}$ & \\
\hline $\begin{array}{l}2006 \text { NFA } \\
\text { (\%GDP) }\end{array}$ & & & & & & $\begin{array}{l}-6.95 \\
(9.11)\end{array}$ \\
\hline $\begin{array}{l}2006 \text { Exports } \\
\text { (\%GDP) }\end{array}$ & & & & & & $\begin{array}{l}-.23 \\
(.17)\end{array}$ \\
\hline
\end{tabular}


Table 5b: Adding Financial and Real Linkages, Simultaneously (US Trade)

\begin{tabular}{|c|c|c|c|c|c|c|}
\hline Linkage & $\begin{array}{l}\text { Exposure } \\
\text { to }\end{array}$ & Default & $\begin{array}{c}\text { Drop } \\
\text { Exchange } \\
\text { Rate Cause }\end{array}$ & $\begin{array}{c}\text { Euromoney, } \\
\text { not II }\end{array}$ & $\begin{array}{l}\text { Condition on } \\
\text { C/acc and } \\
\text { Trade (\%GDP) }\end{array}$ & $\begin{array}{l}\text { Condition on } \\
\text { NFA and } \\
\text { Exports } \\
\text { (\%GDP) }\end{array}$ \\
\hline $\begin{array}{l}\text { Log } 2006 \\
\text { (Population) }\end{array}$ & & $\begin{array}{c}-5.22^{* *} \\
(1.98)\end{array}$ & $\begin{array}{c}-5.36^{* *} \\
(1.93)\end{array}$ & $\begin{array}{c}-5.32^{* *} \\
(1.98)\end{array}$ & $\begin{array}{c}-8.80^{* *} \\
(2.19)\end{array}$ & $\begin{array}{c}-6.89 * * \\
(2.30)\end{array}$ \\
\hline $\begin{array}{l}\log 2006 \\
\text { (GDP p/c) }\end{array}$ & & $\begin{array}{l}-5.42 \\
(9.14)\end{array}$ & $\begin{array}{l}-5.73 \\
(9.04)\end{array}$ & $\begin{array}{l}-5.51 \\
(9.12)\end{array}$ & $\begin{array}{c}-45 \\
(9.59)\end{array}$ & $\begin{array}{c}2.43 \\
(9.91)\end{array}$ \\
\hline $\begin{array}{l}\text { Stock Market } \\
\text { Rise, 2003-6 }\end{array}$ & & $\begin{array}{c}-4.59 * * \\
(1.89)\end{array}$ & $\begin{array}{c}-4.55^{* *} \\
(1.88)\end{array}$ & $\begin{array}{c}-4.59 * * \\
(1.89)\end{array}$ & $\begin{array}{l}-3.90 * \\
(1.75)\end{array}$ & $\begin{array}{c}-5.91^{* *} \\
(2.01)\end{array}$ \\
\hline $\begin{array}{l}\text { CPIS Asset } \\
\text { Share, } 2006\end{array}$ & USA & $\begin{array}{c}.08 \\
(.15)\end{array}$ & $\begin{array}{l}.08 \\
(.14)\end{array}$ & $\begin{array}{l}.09 \\
(.15)\end{array}$ & $\begin{array}{l}-.10 \\
(.15)\end{array}$ & $\begin{array}{l}.01 \\
(.15)\end{array}$ \\
\hline $\begin{array}{l}\text { \% PPG } 2006 \\
\text { Debt in \$ }\end{array}$ & USA & $\begin{array}{l}-.12 \\
(.19)\end{array}$ & $\begin{array}{l}-.11 \\
(.19)\end{array}$ & $\begin{array}{l}.12 \\
(.19)\end{array}$ & $\begin{array}{c}.04 \\
(.22)\end{array}$ & $\begin{array}{l}.11 \\
(.24)\end{array}$ \\
\hline $\begin{array}{l}\text { Exports } \\
2006\end{array}$ & $\begin{array}{l}\text { Small } \\
\text { Crises }\end{array}$ & $\begin{array}{l}-.65 \\
(.46)\end{array}$ & $\begin{array}{l}-.64 \\
(.45)\end{array}$ & $\begin{array}{l}-.66 \\
(.46)\end{array}$ & $\begin{array}{l}-.42 \\
(.44)\end{array}$ & $\begin{array}{l}-.92 \\
(.46)\end{array}$ \\
\hline Trade & USA & $\begin{array}{l}.57^{*} \\
(.24)\end{array}$ & $\begin{array}{l}.57^{*} \\
(.23)\end{array}$ & $\begin{array}{l}.56^{*} \\
(.24)\end{array}$ & $\begin{array}{l}.68^{* *} \\
(.21)\end{array}$ & $\begin{array}{l}.64^{* *} \\
(.23)\end{array}$ \\
\hline $\begin{array}{l}2006 \text { Current } \\
\text { Account } \\
\text { (\%GDP) }\end{array}$ & & & & & $\begin{array}{l}.81 * \\
(.37)\end{array}$ & \\
\hline $\begin{array}{l}2006 \text { Trade } \\
\text { (\%GDP) }\end{array}$ & & & & & $\begin{array}{l}-.17 \\
(.09)\end{array}$ & \\
\hline $\begin{array}{l}2006 \text { NFA } \\
\text { (\%GDP) }\end{array}$ & & & & & & $\begin{array}{l}-4.79 \\
(8.81) \\
\end{array}$ \\
\hline $\begin{array}{l}2006 \text { Exports } \\
\text { (\%GDP) }\end{array}$ & & & & & & $\begin{array}{l}-.24 \\
(.17)\end{array}$ \\
\hline
\end{tabular}

Coefficients, with standard error displayed in parentheses. Coefficients significantly different from zero at .05 (.01) significance level marked by one (two) asterisk(s). Each column represents MIMC estimation on cross-section. Default: 4 consequences (2008 change in Stocks, 2008 Growth, 1-year change in Institutional rating, 2008 Exchange Rate change), fixed loading on stocks. Three control causes (log 2006 population, log 2006 real GDP p/c, 2003-06 stock market decline) included in all runs but not recorded. Adaptive quadrature estimation. 
Figure 1: Exposure to American Assets

2008 Crisis Manifestations against American Assets

Stock Market Change

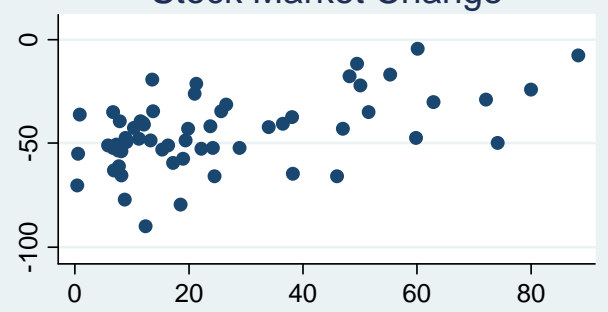

Country Credit Rating Change

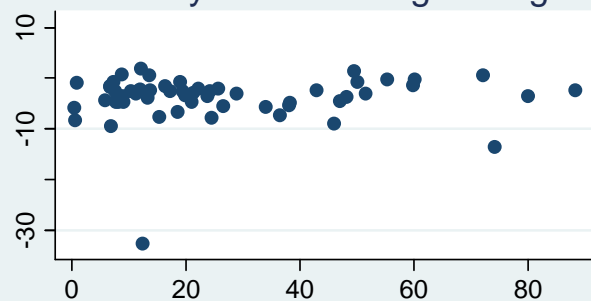

Depreciation against SDR

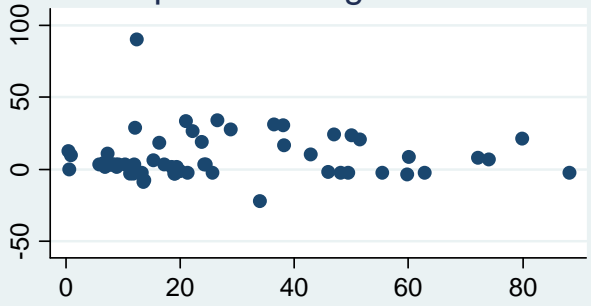

GDP Growth Rate

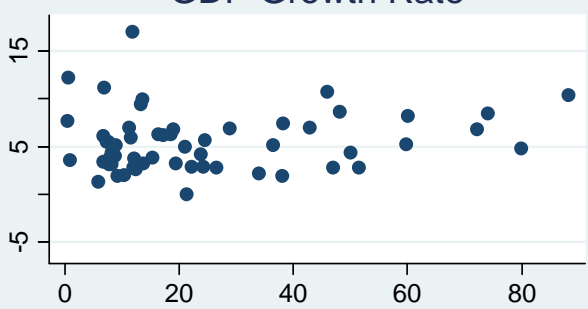

Percentage external assets in US, 2006 CPIS

Figure 2: Exposure to Dollar-Denominated Debt

2008 Crisis Manifestations against Debt in Dollars
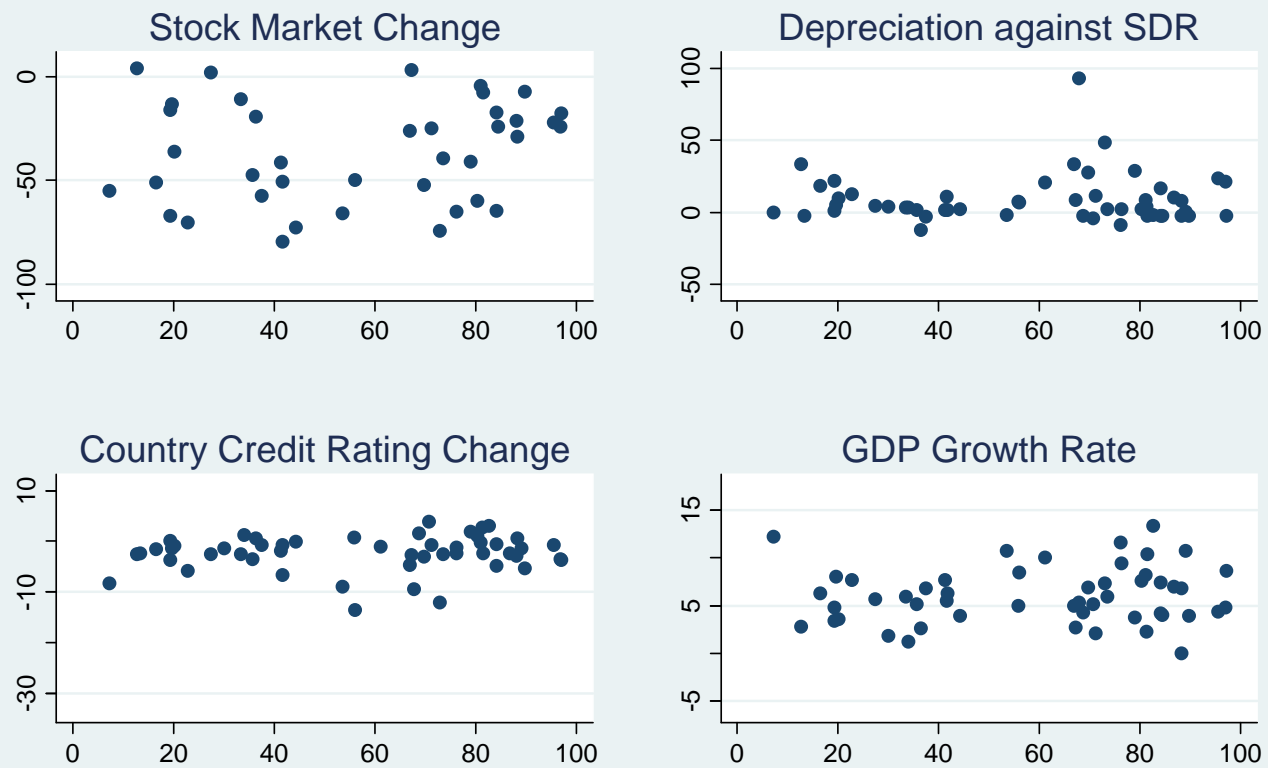

GDP Growth Rate

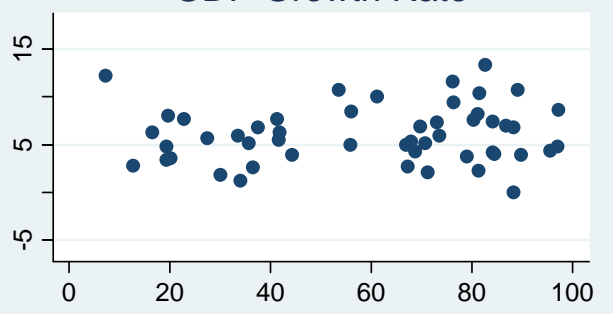

Percentage PPG Debt in US\$, 2006 WDI 
Figure 3: Exposure to America as Export Destination

2008 Crisis Manifestations against American Exports
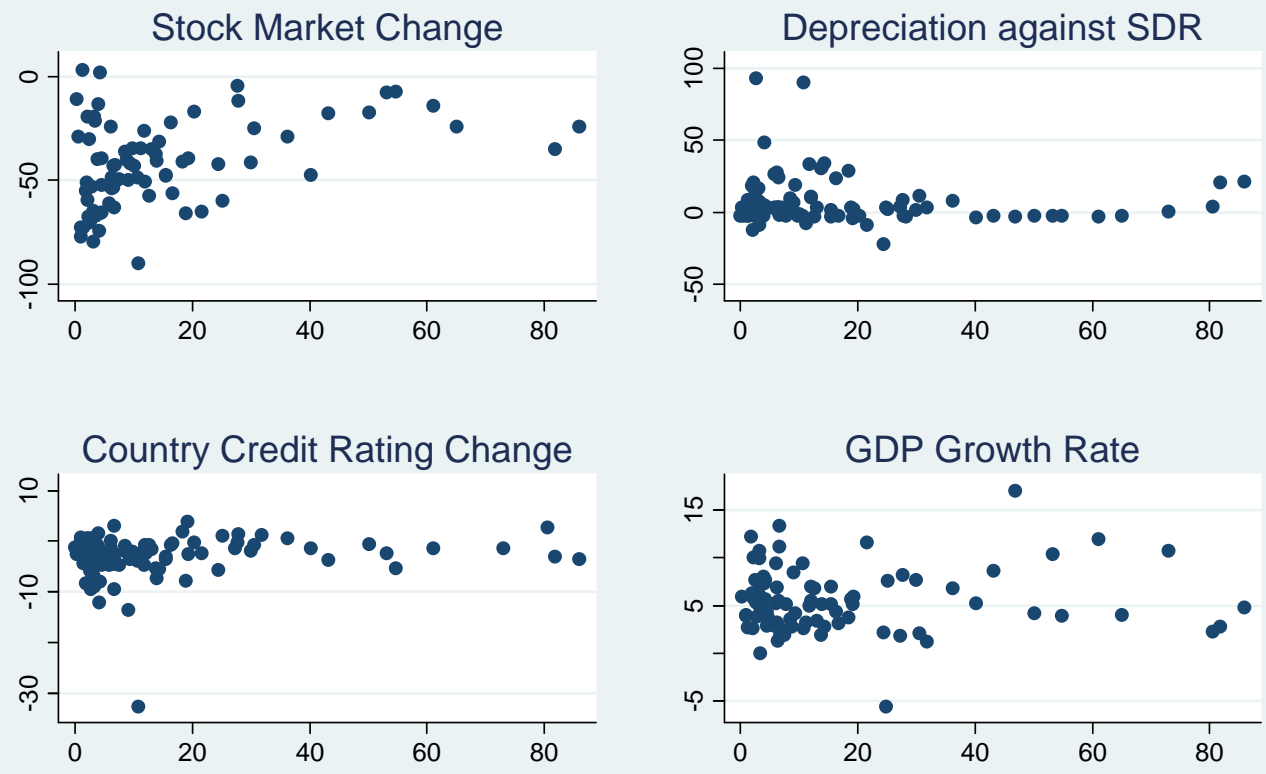

Percentage exports with US, 2006 DoT

Figure 4: Exposure to American Trade

\section{Crisis Manifestations against American Trade}
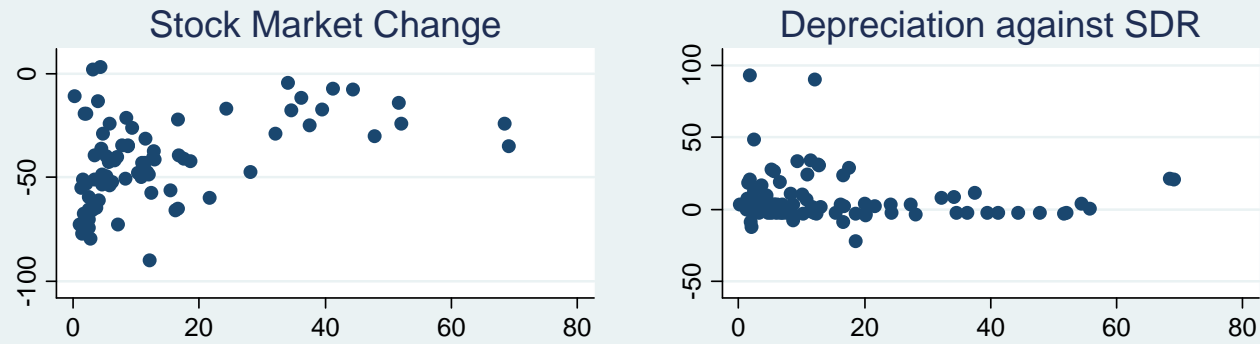

Country Credit Rating Change

GDP Growth Rate
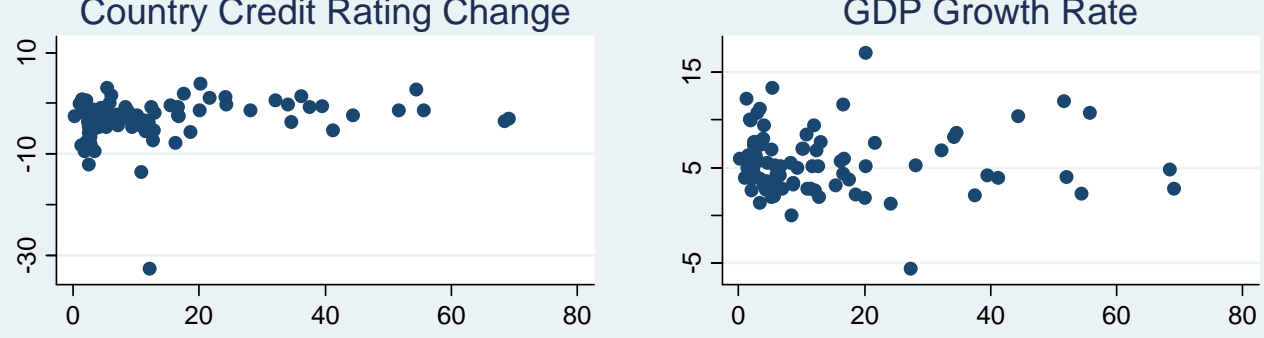

Percentage trade with US, 2006 DoT 
Appendix Table A1: Sample of Countries

\begin{tabular}{|l|l|l|l|}
\hline Argentina & Finland & Lebanon & Russia \\
\hline Armenia & France & Lithuania & Saudi Arabia \\
\hline Australia & Georgia & Luxembourg & Singapore \\
\hline Austria & Germany & Macedonia & Slovakia \\
\hline Barbados & Greece & Malaysia & Slovenia \\
\hline Belgium & Guyana & Malta & South Africa \\
\hline Botswana & Hong Kong & Mauritius & Spain \\
\hline Brazil & Hungary & Mexico & Sri Lanka \\
\hline Bulgaria & Iceland & Morocco & St. Kitts \& Nevis \\
\hline Canada & Indonesia & Namibia & Swaziland \\
\hline Chile & Iran & Netherlands & Sweden \\
\hline China & Ireland & New Zealand & Switzerland \\
\hline Colombia & Israel & Norway & Thailand \\
\hline Costa Rica & Italy & Oman & Trinidad \& Tobago \\
\hline Croatia & Jamaica & Panama & Tunisia \\
\hline Cyprus & Japan & Papua New Guinea & Turkey \\
\hline Czech Rep & Kazakhstan & Paraguay & UK \\
\hline Denmark & Korea & Peru & Ukraine \\
\hline Ecuador & Kuwait & Poland & United States \\
\hline Egypt & Kyrgyzstan & Portugal & Uruguay \\
\hline El Salvador & Latvia & Romania & Venezuela \\
\hline Estonia & & & \\
\hline & &
\end{tabular}




\section{Appendix Table A2: Key Data Sources}

Many of our data series were extracted in early 2009 from the World Bank's World

Development Indicators. ${ }^{21}$ Other key data sets are listed below. The entire (STATA 10.0) data set is available at http://faculty.haas.berkeley.edu/arose/MIMIC2Data.zip.

National Sources

- Percentage change in 2008 broad stock market index

International Monetary Fund, International Financial Statistics

- Percentage change in2008 SDR exchange rate

International Monetary Fund, CPIS

- Table 8: international cross-holdings of portfolio assets, debt, long-term debt

International Monetary Fund, Direction of Trade Statistics

- Bilateral Export and Import flows

Euromoney and Institutional Investor magazines

- Country credit ratings

Economist Intelligence Unit, Country Reports

- 2008 growth estimate as of 3/2009

World Bank, Global Development Finance

- Percentages of Public and Publicly-Guaranteed Debt denominated in dollars and yen

US Treasury, Treasury International Capital System

- Foreign holdings of American Assets, Equity, Long-Term Debt, Debt, Treasuries, and Long-Term Treasuries 


\section{Endnotes}

${ }^{1}$ http://www.europa-eu-un.org/articles/en/article_8284_en.htm

${ }^{2}$ http://ec.europa.eu/commission_barroso/president/pdf/statement_20090225.pdf

${ }^{3}$ We refer below to all these entities as "countries" simply for the sake of convenience.

${ }^{4}$ We use 2003 since we used the Penn World Table Mark 6.2 which ends in 2004 and has a number of missing values for that year. Our measure of income in the PWT6.2 is "rgdpl".

${ }^{5}$ Using 2008 seems like a reasonable choice to us. Though some of the real effects of the crisis began before 2008 (the NBER Dating Committee uses December 2007 as the cyclic peak for the United States), the dramatic downturns took place in the latter part of 2008. Similarly while some financial distress began in the late summer of 2007 (or somewhat earlier), restricting our analysis to the larger events of 2008 seems reasonable, given that our focus is cross-country in nature. But we restrict our attention to crisis causes from 2006 and earlier to avoid any overlap between causes and consequences of the crisis.

${ }^{6}$ The EIU forecast of 2009 growth is highly positively correlated across countries with their 2008 estimates. Since countries have differing underlying growth rates, one would prefer to account for this by e.g., using the size of the output gap, but we know of no source for such data.

7 Institutional Investor states that their ratings "... are based on information provided by senior economists and sovereign-risk analysts at leading global banks and money management and securities firm"; further details are available at: http://www.iimagazinerankings.com/rankingsRankCCMaGlobal09/methodology.asp.

${ }^{8}$ We note in passing that we gathered data on changes in sovereign ratings (short- and long-term on both domestic and foreign debt, as relevant) from Standard and Poor's, Moody's and Fitch. However, these ratings change little over the course of 2008, so we were unable to integrate sovereign rating changes sensibly into our measure of crisis incidence.

${ }^{9}$ Our normalization implies that the latent variable estimate should be interpreted as decreasing in crisis severity.

${ }^{10}$ Much of the previous literature on the determinants of financial crises (e.g. Kaminsky, Lizondo and Reinhart, 1998) and Berg and Patillo, 1999) follow Eichengreen et al (1996) and use discrete characterizations of economies as being in or out of crisis, either in an ad hoc way or based on some objective criteria; this variable as then treated as observed without error. In actuality, the severity of a crisis is like to be a continuous variable, and one that is only observed with error. The MIMIC framework accounts for both measurement error and continuity.

${ }^{11}$ Occasionally we use a different iterative technique to achieve convergence.

${ }^{12}$ We follow Breusch (2005) in choosing to load first on the stock market because it delivers a better fit in a bivariate regression than our three other crisis indicators.

${ }^{13}$ The number of observations available varies by cause because of data availability.

${ }^{14}$ Venezuela, Mexico, Colombia, Bermuda, and Costa Rica all had more than $60 \%$ of their foreign assets in the United States, and had relatively small stock market declines compared with countries with less than $10 \%$ of their foreign wealth invested in America (which include Romania, Latvia, Czech Republic, Estonia, Spain, Austria, and Cyprus).

${ }_{15}$ Details are available at http://www.treas.gov/tic/.

${ }^{16}$ It is worth nothing that this result does not depend on using the exchange rate depreciation as a measure of crisis manifestation; indeed, the fraction of 2006 PPG debt denominated in dollars has a smaller correlation with 2008 depreciation than with e.g., 2008 growth.

17 Little of substance changes if we substitute 2009 growth estimates as a crisis consequence in place of those for 2008.

${ }^{18}$ Iran and Cuba also sent less than $1 \%$ of their exports to the United States, though for more political reasons than the other three countries.

${ }^{19}$ Much of this is not of particular interest, since there is considerable intra-Baltic trade, and the Baltics are all included in the regressions, unlike the regressions which link other countries to e.g., the United States and do not include the United States as an observation (since American cannot export to America).

${ }^{20}$ Again, trade with the small European crisis countries is strongly correlated with greater crisis intensity.

${ }^{21}$ This includes series on: population; real GDP per capita; current account/GDP; stock market capitalization/GDP. 